\section{Research Staff in Ministries}

WRITTEN answers to a series of questions to Ministers on research staff on February 20 in the House of Commons brought the information that the Home Office Research Unit employed 22 professionally qualified staff, and the Department for Industry, Trade and Regional Development employed 25 research officers and 28 statisticians whose duties ineluded research. The Director of an Economic Research Unit at the Board of Trade had also been appointed and would take up his duties on April 1. In the Directorate General of Research and Development of the Ministry of Public Building and Works there were at present 61 professionally qualified staff. The research unit of the Ministry of Power had 44 staff in grades normally requiring a university degree or equivalent qualification as a condition of entry and a further 48 with these qualifications in other grades. The Minister of Transport replied that the research work of the Ministry was not concentrated in a single unit. On the rouds side the Ministry had 8 professionally qualified officers engaged on research, but most research on roads was carried out by the Road Research Laboratory of the Department of Scientific and Industrial Research. The latter Department also undertook some research into shipbuilding and harbour problems, and the Admiralty undertook for the Ministry research on radio-navigational aids for merchant shipping. The Ministry employed an economist who studied problems relating to the shipping industry and six statisticians, part of whose time was spent on research.

\section{Dynamical Climatology in the Meteorological Office}

THe rise of elimatology from the Cinderella of meteorology concerned only with dreary statistics to one of the most fundamental and challenging branches of the subject has been very rapid. Ten year's ago the Meteorological Office formed a division for climatological research, and this was strengthened by incorporating within it the branch concerned with long-range forecasting research. The branch continued to use observational methods in research, but the work of Phillips and Smagorinsky in particular in the United States has shown that a dynamical approach to the problem is possible. In the same way, therefore, that some years ago tho Meteorological Office divided its short-range forecasting research branch into one concerned with observational methods and one concerned with the dynamics of the problem, so the Office has now decided to split the climatological research branch into two. The present head, Mr. M. H. Freeman, will become assistant director for synoptic climatological research, earrying the responsibility for long-range forecasting. The new branch, for dynamical climatological research, will be headed by $\mathrm{Mr}$. G. A. Corby, and will have the task of investigating the fundamental theoretical behaviour of the atmosphere, or the general eirculation. Mr. Corby has had much experience both in dynamical meteorology and in the problems of using electronic computers for numerical forecasting, and he is thus well fitted to lead his team into this new field.

\section{The Commonwealth and International Library}

ON February 19, Pergamon Press, Ltd., Oxford, published the one-hundredth volume in the Commonwealth and International Library, the 1,000-volume educational series launched on May 23, 1962 (Nature, 194, 631; 1962), with messages of good will from such leading Commonwealth statesmen as Jawaharlal Nehru, Field Marshal Ayub Khan, Sir Abubakar Tafawa Balewa, Prime Minister of the Federation of Nigeria, and Tunku Abdul Rahman of Malaysia and with the co-operation of leading educators and industrialists throughout the English-speaking world. This milestone in the progress of a major British publishing venture was marked by a reception given by Sir Robert Robinson, joint chairman of the Honorary Editorial Advisory Board, and Mr. Robert Maxwell. chairman of
Pergamon Press, at the Commonwealth Institute in London on February 19; and by exhibitions in the United Kingdom and in major Commonwealth capitals of the first 100 books. The authors of the hundredth publication, a two-volume work entitled Iiberal Studies : an Outline Course, are N. C. Dexter of Corby Grammar School and E. G. Rayner of Wyggeston Grammar School. This work selects topies from a wide field-education, art, religion, sociology, politics and philosophy-and presents them in a manner calculated to provoke serious thought about. and discussion of, the many problems which face voung people to-day.

The Commonwealth and International Library was started to meet the growing demands for up-to-date and authoritative books at a price which students all over the world can afford, and is now providing original books and reference books for full- and part-time students, for apprentices in industry, for teachers, and for the intelligent layman. The majority of the books are priced between $10 s$. and $21 s$. and are bound in washable, flexible covers; but a special hard-case edition is available for libraries. There are more than sixty subject divisions which eater for school-children from twelve upwards to the sixth form, on to university and, finally, to postgraduate studies. Teaching aids such as film strips, tape-recordings and wall charts are available to augment the books. The complete range of newly compiled atlases is now in production.

\section{The American Museum of Natural History, New York}

THw chiof responsibility of this Museum is to educate the public in natural science, and this has cortainly been achieved satisfactorily, as the report for 1962-63 indicate a total attendance of more than three million visitors ( $\mathrm{Pp}$ 96. New York: The American Museum of Natural History, 1963). The Hall of the Biology of Man and the exhibit "Man in Space" were the newer displays that attracted attention, and long-standing favourites, such as the halls dealing with African mammals. North American mammals and forests and the dinosaur, continued to draw visitors. A relatively large staff for a museum is in each department actively engaged in research on many projects. Work on both the design and preparation of exhibits for the Hall of the Biology of Invertebrates is progressing and designs for the exhibits in the Hall of the Peoples of Africa are completed.

\section{Tea Growing in East Africa}

Tea (Journal of the Tea Boards of East Africa, 4, No. 3; Oetober 1963) lists the prize-winners for quality East African teas. Quite a few names are in the two classes, teas made by the orthodox method of manufacture and those made by other methods. The Chairman of the 'Tanganyika Growers' Association reports progress made in the culture and manufacture of tea in an area at present experiencing political growing pains. There has been a considerable increase in African small holdings, some, regrettably, stocked with poor planting material. A spate of legislation has been introduced affecting tea planting, not all welcome to the industry. Thus, there is now an export tax on tea, but some satisfaction is expressed that a flat rate of 10 cents per $\mathrm{lb}$. has been adopted and not, as originally proposed, a tax ad valorem. The Kenya Tea Growers' Association reports that the Tea Plantation Workers' Union has now been amalgamated with the Coffee and Sisal Plantation Workers" Union and the General Agricultural Workers' Union. Evidontly Union amalgamation is not a matter of moment only in the morr developed countries. A report is included of the first course to be held by the Tea Research Institute of East Africa on the science of tea growing-a short course of about a week. The Institute also plans to make available new clonal material. The Chairman of the Tanganyika Association pertinently remarks that new techniques of 